\title{
sciendo
}

CIVIL AND ENVIRONMENTAL ENGINEERING REPORTS

E-ISSN 2450-8594

CEER 2021; 31 (3): 0197-0210

DOI: 10.2478/ceer-2021-0041

Original Research Article

\section{DIAGNOSTICS AND REPAIRS OF DAMAGE OF THE LEANING TOWER IN ZABKOWICE SLASKIE}

\author{
Tomasz ABEL ${ }^{1}$ \\ Wroclaw University of Science and Technology
}

\begin{abstract}
The article concerns the diagnosis of the technical condition, as well as the possibilities of renovating, the Leaning Tower located in Zabkowice Slaskie in Lower Silesia, Poland. Damage to the structure of the facility, which occurred in 2015, constituted the basis for carrying out tests and measurements in order to enable the causes of the damage to be determined. The resulting damage is cracks in brick walls. Cracks were formed in the place where the proper structure of the Tower was connected with the staircase constituting the extension of the building. Therefore, it was necessary to carry out diagnostic work. The conducted diagnostic works resulted in the obtaining of knowledge about the technical condition of the facility, and the possibilities of the necessary repair works, which will ensure the further safe operation of the facility. It was considered necessary to stabilize the ground under the staircase by making micropiles. Cracks in the walls were stabilized by making steel ties, rebuilt and reinforced with steel bars. The Leaning Tower, as a historic and unique building in Europe, requires special technical supervision, which will guarantee that it remains in its prime for many years to come and continue to be one of the key tourist attractions of Zabkowice Slaskie.
\end{abstract}

Keywords: repairs of masonry structures, micropiles, belfry, tower, historic buildings

\footnotetext{
${ }^{1}$ Corresponding author: Wroclaw University of Science and Technology, Wybrzeże Wyspiańskiego 27, tomasz.abel@pwr.edu.pl, +48 713203237
} 


\section{DESCRIPTION OF THE FACILITY}

The Leaning Tower is a rare Gothic example of a free-standing belfry. The facility is located on the street named St.Wojciech in Zabkowice Slaskie in the immediate vicinity of the church of St. Anna. The tower is in a line with terraced tenement houses, has eight floors, and its south-eastern wall partially adjoins a residential and service building.

The lower part of the tower is made of crushed stone up to a height of about $5 \mathrm{~m}$ above the ground, and its higher part is made of solid brick with lime mortar. The lowest storey, about $10 \mathrm{~m}$ above ground level, is covered with a cross-shaped ceramic vault made of solid brick and filled with a backfill on which joists and a wooden floor are placed. The ceilings of the upper storeys are wooden and covered with flooring. The roof of the building has a wooden structure, is hipped, and covered with a copper sheet. An outbuilding adjoins to the south-west side of the tower, and is an entrance to its lowest level. From this level it is possible to get to the "starvation" dungeon located below the central part of the tower. In the outbuilding there are fan-shaped sandstone stairs, and in the central part of the tower there are corridors with brick stairs lined with wooden treads. In the upper part of the tower, there are wooden, single-speed ladder stairs. The Tower is shown on Fig. 1.

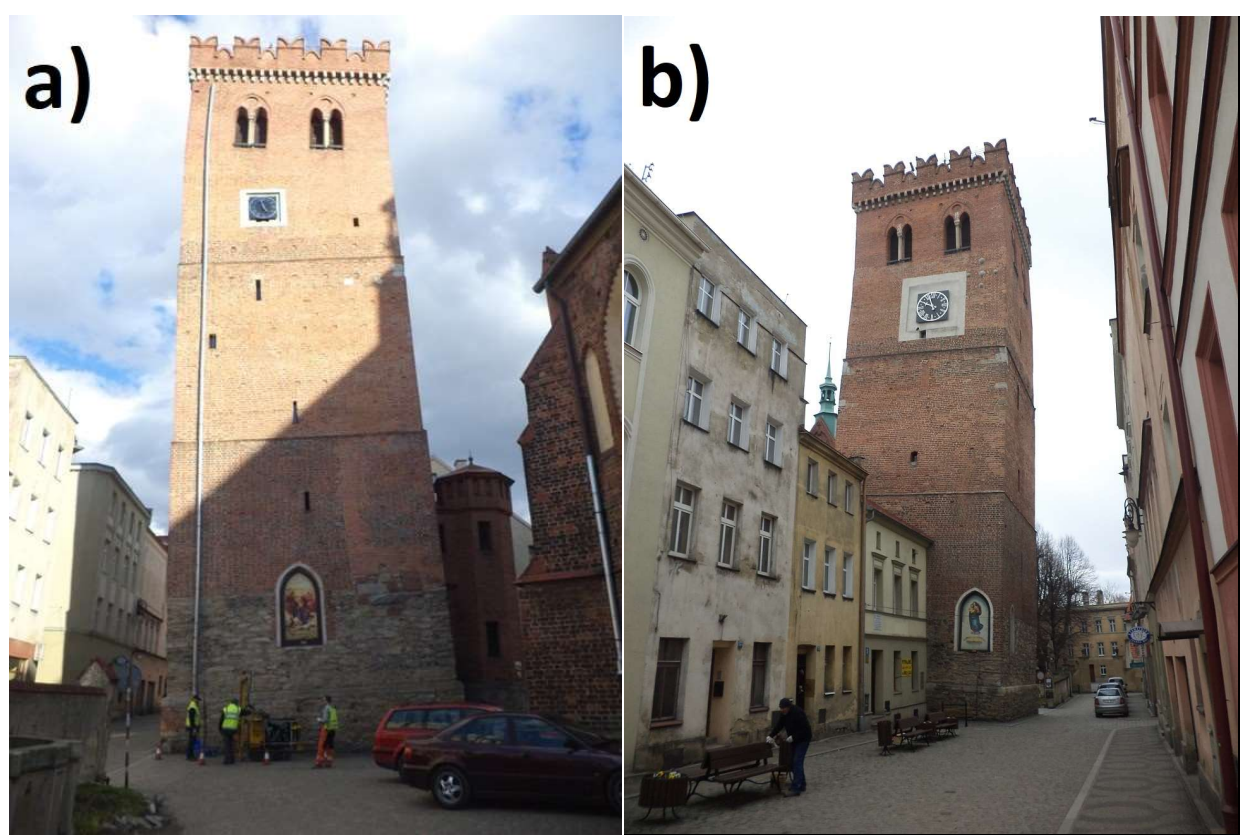

Fig. 1. View of the tower: a) east facade, b) west facade 


\section{CHARACTERISTICS OF DAMAGE}

In March of 2016, geotechnical tests and a visual inspection of the facility were carried out, an inventory of damage was conducted, and the condition of individual structural elements was determined.

As a result of expert works, the occurrence of cracks and scratches was found at the connection of the tower with the outbuilding, which is a housing for the fanshaped stairs leading to the first usable level of the Leaning Tower (see Fig. 2).

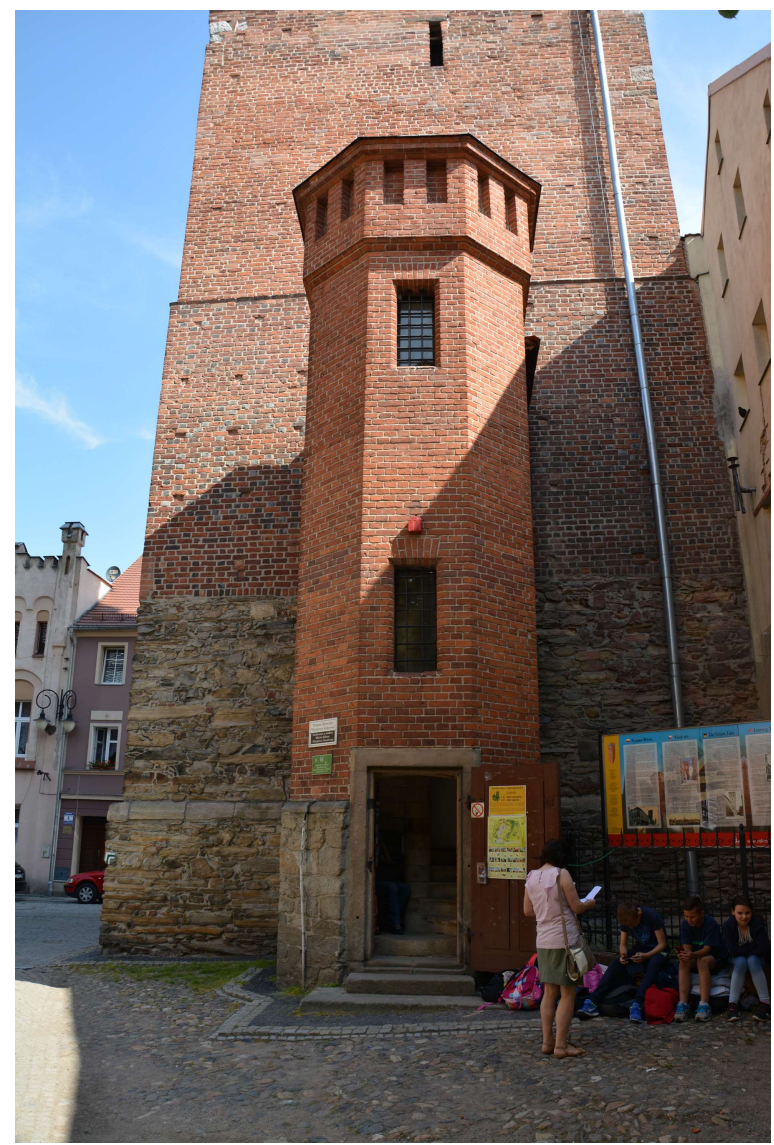

Fig. 2. View of a part of the tower and outbuilding

The cracks and scratches of the structural elements - at the connections of the walls of the outbuilding with the south-west wall of the tower - are continuous cracks that occur along the entire length of the elements and which propagate through the elements into their interior, as shown in the photo documentation below (Fig. 3). 
Apart from the damage described above, no other irregularities were found. The visual inspection of the facility did not reveal any other dangerous phenomena. Similar damage is described in the paper [2].

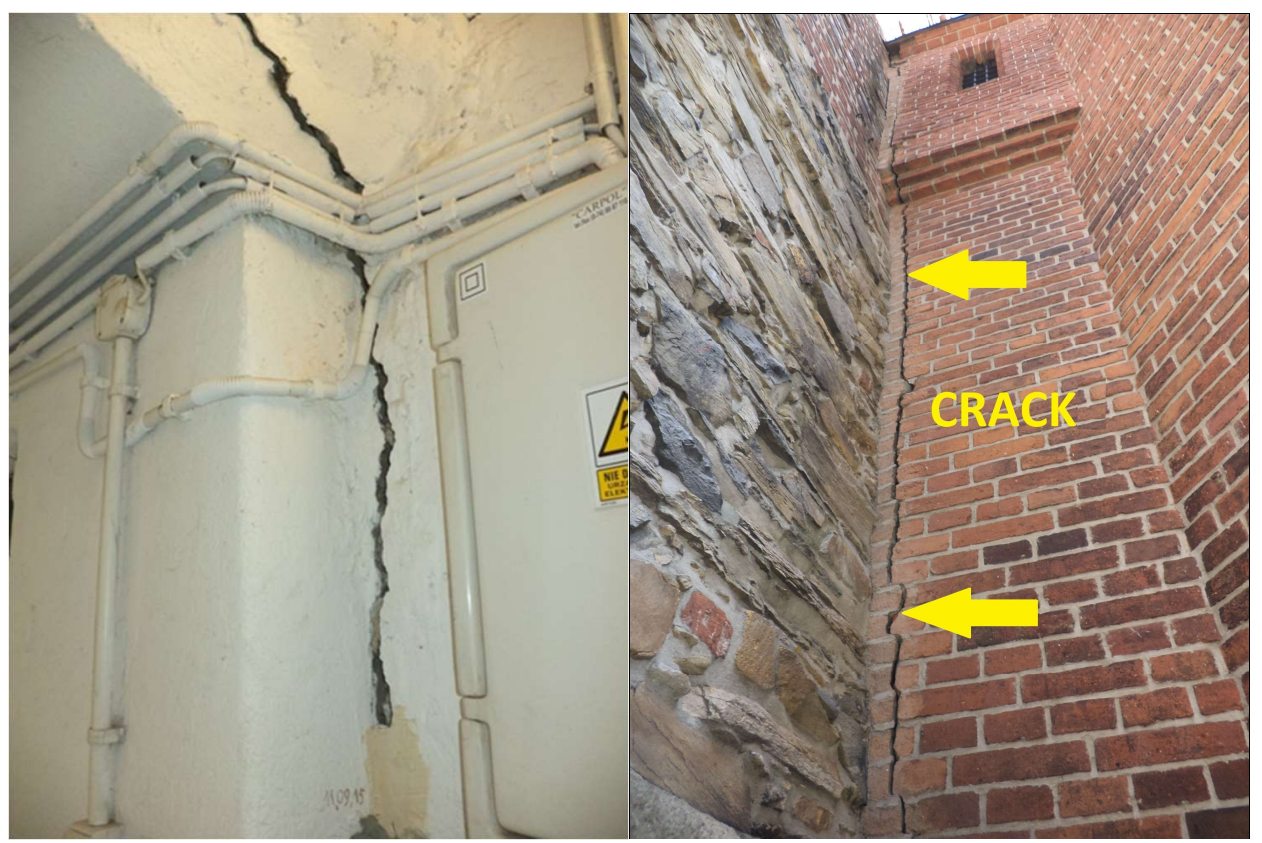

Fig. 3. Crack at the connection of the tower and the outbuilding - the view from inside and outside

\section{ANALYSIS OF THE CAUSES OF DAMAGE TO THE FACILITY}

Based on an interview conducted among people directly responsible for using and making the facility available to tourists, it was found that the cracks and scratches observed on the tower mainly occurred in 2015 . Moreover, at that time, the already existing scratches and cracks also propagated.

Therefore, it was necessary to analyse the recent changes that could have occurred in the soil medium. The basic factors that could influence the occurred phenomena include:

- the groundwater level, seepage in cohesive soils, water suspended on cohesive soils,

- the type of soils lying horizontally and below the foundation level,

- the different levels of foundations of the tower and outbuilding. 


\subsection{The hydrogeological situation in $\mathbf{2 0 1 5}$}

Based on an analysed report concerning the current hydrogeological situation [1], it can be concluded that in the summer of 2015 there were unfavourable atmospheric phenomena that may have had a direct impact on the condition of the groundwater in the vicinity of the tower, namely:

- in the third quarter of the hydrological year of 2015, most observation points (wells and piezometers) recorded a decrease in the average level of the groundwater table in relation to its position in the previous quarter,

- in Poland, in most of the analysed research points, the groundwater table decreased,

- the summer of 2015, in terms of the thermal conditions in most of Poland, was higher than the norm, and in the south of the country much higher than the norm,

- precipitation was below the norm in most of Poland in the summer of 2015.

In the third quarter of the hydrological year of 2015, the phenomenon of the decrease in the average level of the groundwater table in relation to the previous quarter was dominant throughout the country. This phenomenon continued in the following months. This situation occurred throughout the year, and intensified in its latter months. In May, a decrease in the groundwater table was recorded in approx. $80 \%$ of the analysed measuring points, in June - in over $81 \%$, and in July - in almost $87 \%$. In the following weeks (the first two weeks of August), this process continued and covered $90.5 \%$ of the measuring points.

Regarding the above, and due to the topography of the area (large inclination towards the north-west), it can be concluded that the groundwater level in the area where the facility is located has a tendency to decrease.

\subsection{Local changes in rainwater management}

The groundwater levels (regardless of the form of their occurrence) were directly influenced by external factors related to the works that involved the tidying up and spatial development of the surrounding area. The visual inspection of the facilities and areas directly adjacent to the tower showed the following with regards to what happened before the occurrence of damage in the immediate vicinity of the tower:

- the surface of the parking lot was concreted - which reduced the inflow of rainwater that supplements groundwater resources,

- the roof drainage system of the Church of St. Anna was fixed, which limited the inflow of rainwater to the ground. 
Both of the above-mentioned changes could have been an additional factor that locally influenced the change in the groundwater level i.e. causing its decrease.

\subsection{Geological conditions}

The area adjacent to the foundations of the structure consists mostly of compacted silty clay soils with layers of loam. The layers of the aforementioned soils occur to about $3.0 \mathrm{~m}$ below the surface area. Lower down, there are coarse and medium sands with gravel, which are characterized by a much higher load-bearing capacity. Both cohesive silty clay and loam are cohesive soils that are characterized by the phenomenon of contraction [13]. The contraction of soil involves the reduction of its volume as a result of the separation of water during drying, or is due to the development of physicochemical processes (osmosis). Only moist soil has the ability to contract. As a result of contraction, the soil becomes more compact, and after drying even hard [12]. The compaction of cohesive soil with contraction reduces its susceptibility to deform. However, the presence of cracks, usually associated with contraction, increases water permeability and reduces the stability of the soil's surface layer.

The probable change in the moisture content of the soils located just under the tower's outbuilding caused a change in their volume, which resulted in the phenomenon of subsidence and the formation of cracks at the interface between the two elements (Fig. 4).

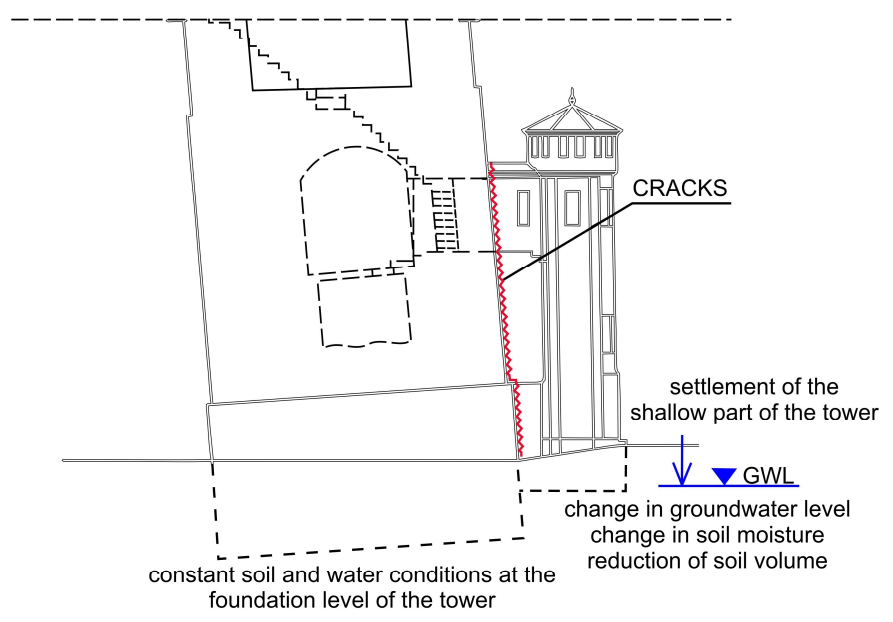

Fig. 4. Schematic diagram of the emerging phenomena 


\subsection{Conclusions}

The analysis of the occurring phenomena and the determination of the geotechnical conditions for the foundations of the object show the complexity of the causes of the damage. Damage to the tower's structure is a result of the following factors:

- unstable cohesive soils in the level of the foundations of the outbuilding,

- changes in the groundwater level,

- two different levels of foundations of individual parts of the facility.

\section{ANALYSIS OF GEODESICAL MEASUREMENTS}

As part of the implementation of the task in question, the prepared geodetic surveys were analyzed. The basic measured values are presented in Table 1.

Table 1. The results of geodetic surveys

\begin{tabular}{|c|l|c|c|}
\hline No. & \multicolumn{1}{|c|}{ Measured value (see Fig. 5) } & $\mathbf{0 3 . 1 2 . 2 0 1 3}$ & $\mathbf{0 3 . 1 0 . 2 0 1 5}$ \\
\hline $\mathbf{1}$ & Deviation from vertical axis $\mathrm{L}_{1}$ & $1.928 \mathrm{~m}$ & $1.926 \mathrm{~m}$ \\
\hline $\mathbf{2}$ & Deviation from vertical axis $\mathrm{L}_{2}$ & $1.816 \mathrm{~m}$ & $1.822 \mathrm{~m}$ \\
\hline $\mathbf{3}$ & Max. perpendicular deflection $1_{\max }$ & $1.926 \mathrm{~m} \pm 3 \mathrm{~mm}$ & $1.924 \mathrm{~m} \pm 3 \mathrm{~mm}$ \\
\hline $\mathbf{4}$ & Max. lateral deviation $\mathrm{d}_{\max }$ & $1.995 \mathrm{~m} \pm 5 \mathrm{~mm}$ & $1.996 \mathrm{~m}$ \\
\hline $\mathbf{5}$ & Object height at point 1 & $32.458 \mathrm{~m}$ & ----- \\
\hline $\mathbf{6}$ & Object height at point 2 & $32.877 \mathrm{~m}$ & ----- \\
\hline
\end{tabular}

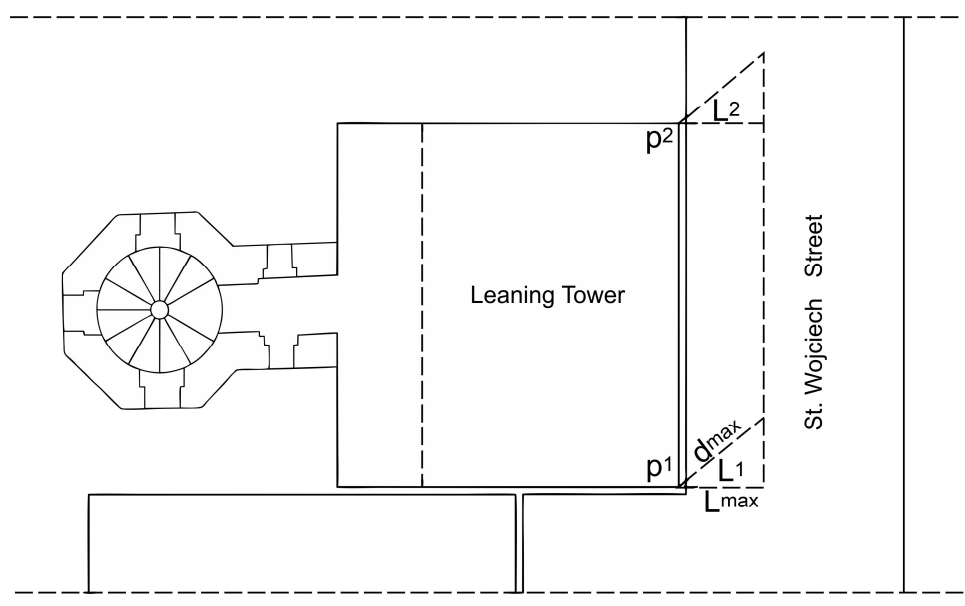

Fig. 5. A situational sketch showing the measured values 
As can been seen from the conducted measurements and conclusions contained in the geodetic surveys , the maximum deflection of the tower did not change in the period from 2013 to 2015 . The authors of the geodetic study recommended periodic tests of displacements and deformations, as well as the object's settlement. Such tests, thanks to the monitoring of changes in the location of control points, ensure the safety of using the facility and enable timely preventive measures to be implemented in order to prevent failures and construction disasters.

\section{VERYFYING CALCULATIONS}

In order to confirm the stability of the tower, verifying calculations (assuming unfavorable loading conditions) were performed. They involved the determination of the place of action of the resultant stabilizing force of the tower and the carrying out of the verification of the structure with regards to its rotation [3].

\subsection{Determination of the centre of gravity of the inclined cross-section}

By projecting force $\mathrm{P}$ onto the foundation's base, it is possible to determine the arm of its action, which in this case is equal to approximately $1.30 \mathrm{~m}$. The core of the tower's foundation - $B=(10,0 \mathrm{~m}) 6$ - is equal to $1.66 \mathrm{~m}$. Therefore, the force remains inside the core, which is shown in Figure 6.

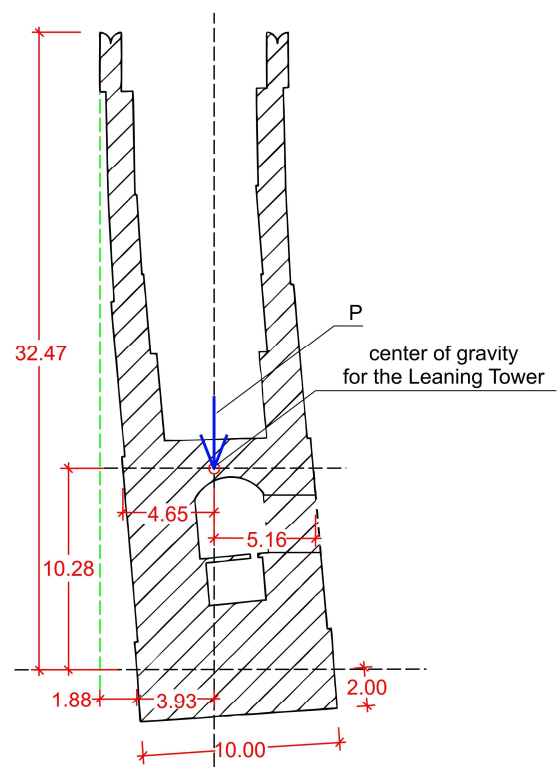

Fig. 6. Location of the centre of gravity and the stabilizing force (P) 


\subsection{Stabilizing force - the self-weight of the object}

The self-weight of the object should be considered as the basic stabilizing force. Due to the massive form of the tower's structure and the fact that it has direct foundations, i.e. a foundation block that transfers loads through its entire surface, this solid is characterized by good stability.

The value of the stabilizing force acting on the soil is not less than $\mathrm{P}=40,000.00 \mathrm{kN}$, which when distributed over the foundation's contact area is equal to:

$$
p=\frac{40.000,00 \mathrm{kN}}{100,00 \mathrm{~m}^{2}}=400,00 \frac{\mathrm{kN}}{\mathrm{m}^{2}}
$$

\subsection{Overturning force - wind load}

Wind load was assumed as the basic force that exerts pressure on the tower's walls. The maximum wind load for a given zone, which is significantly higher than the standard mean value, was assumed for the calculations.

$$
f_{\text {wind }}=0,5 * \rho * V^{2} * 2,3 *\left(\frac{h}{10 m}\right)^{0,24}
$$

where:

$\rho$ - air density $\left(1,2 \mathrm{~kg} / \mathrm{m}^{3}\right)$,

$\mathrm{V}$ - wind speed $(\mathrm{m} / \mathrm{s})$, zone III and the maximum value of $30 \mathrm{~m} / \mathrm{s}$ were assumed in the calculations,

$\mathrm{h}-$ height for which the value of wind load is determined.

In accordance with the guidelines included in Eurocode 1 [4], the pressure values at the following levels were determined - see Table 2.

Table 2. Pressure values

\begin{tabular}{|l|l|l|l|l|l|l|l|}
\hline 1 & $\mathrm{~h}=[\mathrm{m}]$ & 10,00 & 13,00 & 16,20 & 19,40 & 22,50 & 32,50 \\
\hline 2 & $\mathrm{f}_{\text {wind }}=\left[\mathrm{kN} / \mathrm{m}^{2}\right]$ & 1,242 & 1,316 & 1,391 & 1,453 & 1,503 & 1,648 \\
\hline
\end{tabular}

\subsection{Calculation of the value of the reaction of soil}

The value of reaction of soil was calculated using a formula (5.3). The obtained values were used to check the stability of the structure.

$$
\begin{gathered}
q=\frac{P}{B * L} \pm \frac{P * e}{W} \\
q_{\text {max }}=712,01 \mathrm{kN} / \mathrm{m}^{2} \quad q_{\text {min }}=87,98 \mathrm{kN} / \mathrm{m}^{2}
\end{gathered}
$$




\subsection{Checking the stability condition with regards to rotation}

The general verification of the tower's stability with regards to rotation was performed in relation to the most unfavourable point in the structure (point A in Fig. 7) using formula:

$$
M_{\text {or }} \leq m_{o} * M_{u r}
$$

where:

$\mathrm{M}_{\mathrm{or}}$-the moment of all the forces that cause rotation of the structure, $\mathrm{m}_{\mathrm{o}}$ - the safety reduction factor $(0.8$ was assumed $)$,

$\mathrm{M}_{\mathrm{ur}}$ - the moment of all the forces that counteract the rotation of the structure.

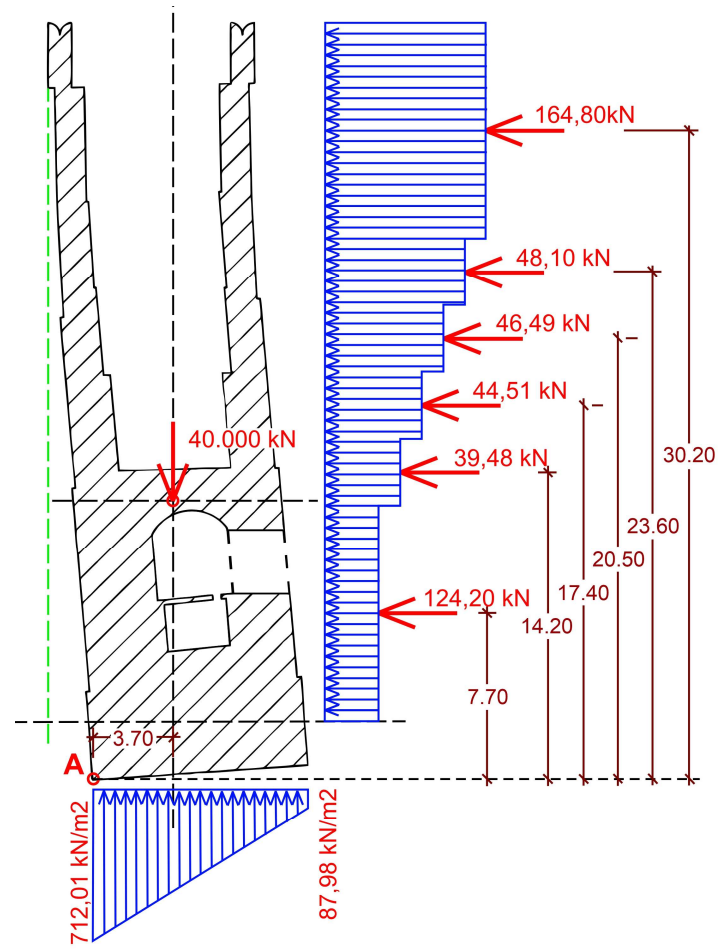

Fig. 7. Summary of the forces acting on the object

$\mathrm{M}_{\mathrm{ur}}=40.000,00 \mathrm{kN} * 3,70 \mathrm{~m}=\mathbf{1 4 8 . 0 0 0 , 0 0} \mathbf{~ k N m}$

$\mathrm{M}_{\mathrm{or}}=124,20 \mathrm{kN} * 7,70 \mathrm{~m}+39,48 \mathrm{kN} * 14,20 \mathrm{~m}+44,51 \mathrm{kN} * 17,40 \mathrm{~m}+46,49$ $\mathrm{kN} * 20,50 \mathrm{~m}+48,10 \mathrm{kN} * 23,60+164,80 \mathrm{kN} * 30,20 \mathrm{~m}=\mathbf{9 . 3 5 6 , 5 8} \mathbf{~ k N m}$

$9.358,58 \mathrm{kNm} \leq 0,8 * 148.000,00 \mathrm{kNm}=118.400,00 \mathrm{kNm}$ 


\subsection{Calculation results}

As a result of the static analysis, it was shown that:

- the centre of gravity of the object, and also force P, are located in the foundation's core, which positively affects the stability of the object,

- at the level of the foundations, the arm of the resultant holding force is relatively small (approximately $1.3 \mathrm{~m}$ ), and therefore the phenomenon of the "overturning moment" does not arise,

- the analysis of the maximum horizontal force that results from the wind load, which is considered as the basic component of the "overturning loads", as well as the verification of the condition for rotation show that the moments that can cause overturning are approximately 12 times lower than the moments that maintain the stability of the tower,

- there is no risk of the tower losing stability.

\section{REPAIR SOLUTION}

In the course of expert works concerning damage to the tower's structural elements, it was found that the stability of the tower is not endangered and that the damage refers only to the outbuilding. This damage results from the changing soil and water conditions, as well as the different levels of the foundations.

Due to the propagation of the damage, which was stated during the inspection and inventory carried out at the turn of May and June 2018, it was decided to stabilize the outbuilding, which would enable its further safe use.

The following works were performed $[5,6,7,8,11]$ :

- the execution of steel ties connecting the outbuilding with the tower,

- the execution of micropiles - reinforcement of the foundations [9],

- the repair of existing scratches and cracks,

- rebricking of damaged elements.

\subsection{Steel ties}

In order to protect the structure of the outbuilding (staircase) against progressive horizontal displacements (a secondary phenomenon resulting from the settlement of the object), steel ties made of $\varphi 30 \mathrm{~mm}$ bars were installed on three levels (see Fig. 8), namely:

- level I - main ties were installed "through" the structure of the building above the stairs outside the communication zone - at the level of about $8.40 \mathrm{~m}$ above ground level (above the windows of the corridor that connects the staircase with the tower),

- level II - additional ties were installed at the level of $7.00 \mathrm{~m}$ above ground level (under the corridor windows) - the ties ended on the wall of the 
staircase; the recesses were cut out in the wall for mounting the retaining sheets,

- level III - additional ties were installed at the bottom of the tower's "starvation" dungeon.

\subsection{Micropiles}

The micropiles were designed with the use of cement mortar injection, which causes the enlargement of the pile's diameter in the area of the load-bearing soils. They were made of perforated steel thick-walled pipes with an outer diameter of $180 \mathrm{~mm}$ and a wall thickness of $10 \mathrm{~mm}$ (reinforcement pipe). The pipes reached the offset level of the existing stone foundation (the offset level is approx. at $0.2 \mathrm{~m}$ below ground level). The axis of each pile was $35 \mathrm{~cm}$ from the edge of the walls of the outbuilding.

In order to obtain a complete joining of the existing foundation with its concrete envelope, which transfers the load to the micropiles, anchors made of steel bars chemically attached to the existing foundation and connected with the reinforcement of the concrete envelope were made.

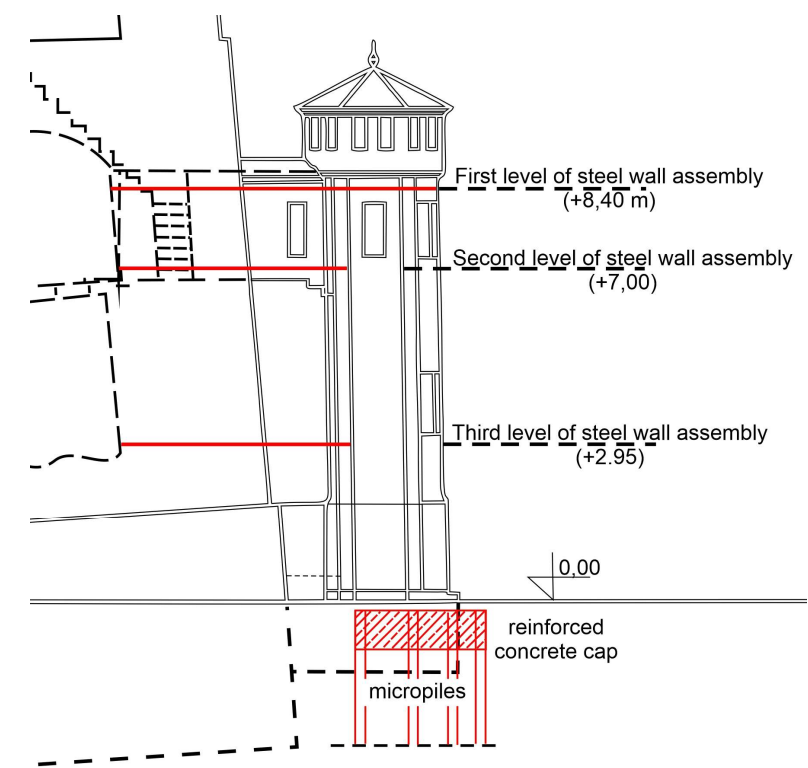

Fig. 8. Method of strengthening the object - steel ties and micropiles

\subsection{Repairs of scratches and cracks}

In order to locally reinforce and recreate the continuity of the construction elements, stitching reinforcement was installed from the inside. Ribbed bars with 
a diameter of $6-10 \mathrm{~mm}$ were used. The bars were fixed in grooves that were cut in the joints perpendicular to the crack. After embedding the bars, the joints were filled with polymer cement concrete (PCC) mortar that had a compressive strength of no less than $25 \mathrm{MPa}[10,11]$.

The existing cracks were filled with a low-viscosity cement suspension. Injection using this type of material guarantees that the repaired crack will be durable and that good strength parameters will be ensured.

The pressure method of filling the cracks was used, with the cracks being previously protected against the leakage of the suspension, e.g. using PCC putty or other renovation mortar.

The cracks on the outer side of the wall were filled with renovation mortar at the stage of performing surface sealing.

\subsection{Rebricking of the damaged fragments of the walls}

Strongly cracked wall fragments above the windows (fragments of lintels) in the passage between the staircase and the tower (see Fig. 3), which had cracks with a large width (over $10 \mathrm{~mm}$ ), were rebricked. The purpose of the rebricking was to recreate the original connection between the bricks, while at the same time to ensure the joining of the parts of the wall separated by the cracks.

Bricks taken from demolitions, or bricks with similar properties to the original ones, as well as mortar similar to the original one in the wall (renovation mortar systems), were used. The brickwork was performed partially - first one brick deep from the inside, then one brick deep from the outside. In order to avoid the formation of shrinkage scratches at the connections between the old and new walls, anchoring reinforcement and renovation non-shrink mortars were used [10, $11]$.

\section{CONCLUSION}

The renovation works, which were performed in order to stabilize the foundations of the outbuilding and its connection with the Leaning Tower, constituted the basis for the scope of the construction works. The conducted works ensured the stopping of the progression of the cracks in the walls at the connection between the two buildings, and enabled the further safe operation of the facility. Additional renovation works, which involved the repairing of damage, such as cracks in the walls, aimed to remove all the visible effects of the subsidence of part of the Leaning Tower, i.e. the outbuilding that serves as the entrance to the facility. The comprehensively performed renovation works resulted in the restoring of the appropriate technical condition of the building, therefore making it available to tourists again. 


\section{REFERENCE}

1. Communication on the current hydrogeological situation-3rd quarter of the hydrogeological year 2015 (Komunikat o bieżacej sytuacji hydrogeologicznej - III kwartat roku hydrogeologicznego 2015). Warsaw, Polish Geological Institute.

2. Drobiec, $Ł$ 2015. Repair of cracks and strengthening of masonry walls (Naprawa rys i wzmocnienia murowanych ścian). Szczyrk, XXX Jubilee National Workshop for Structural Designers 25 - 28 March, p. 323-398.

3. Eurocode 1, EN 1991-1-1 Part 1-1 General impacts. Volumetric weight, selfweight, imposed loads in buildings - Actions on structures. (Oddziatywania ogólne. Ciężar objętościowy, ciężar własny, obciązenia użytkowe w budynkach - Oddziatywania na konstrukcje).

4. Eurocode 1, EN 1991-1-4 Part 1-4 General impacts. Wind actions. (Oddziaływania ogólne. Oddziaływania wiatru).

5. Jasieńko, J and Łodygowski, T 2006. Repair, maintenance and strengthening of the selected, historic brick structures (Naprawa, konserwacja $i$ wzmacnianie wybranych, zabytkowych konstrukcji ceglanych). Wroclaw, Lower Silesian Educational Publisher.

6. Małyszko, L and Orłowicz, R 2000. Masonry structures. Scratches and repairs (Konstrukcje murowe. Zarysowania i naprawy). Olsztyn, Publishing house of the University of Warmia and Mazury.

7. Małyszko, L and Orłowicz, R 2008. Selected methods of repairing scratched masonry walls (Wybrane sposoby napraw zarysowanych ścian murowych). Review, no 12, p. $40 \div 46$.

8. Masłowski, E and Spiżewska, D 2000. Strengthening building structures (Wzmacnianie konstrukcji budowlanych). Warsaw, Arkady.

9. PN-EN 14199:2015-07 Execution of special geotechnical works. Micropiles (Wykonawstwo specjalnych robót geotechnicznych. Mikropale).

10. Rudziński, A 2006. Masonry structures. Renovations and reinforcements (Konstrukcje murowe. Construction Remonty $i$ wzmocnienia). Kielce, Publishing house of the Kielce University of Technology.

11. Stawiski, B 2014. Masonry structures - Repairs and reinforcements (Konstrukcje murowe - Naprawy $i$ wzmocnienia). Warsaw, Polocen Publishing House.

12. Szymański, A 2007. Soil mechanics (Mechanika gruntów). Warsaw, SGGW Publishing House.

13. Wiłun, Z 2013. Outline of geotechnics (Zarys geotechniki). Warsaw, WKt Publishing House.

Editor received the manuscript: 19.04.2021 